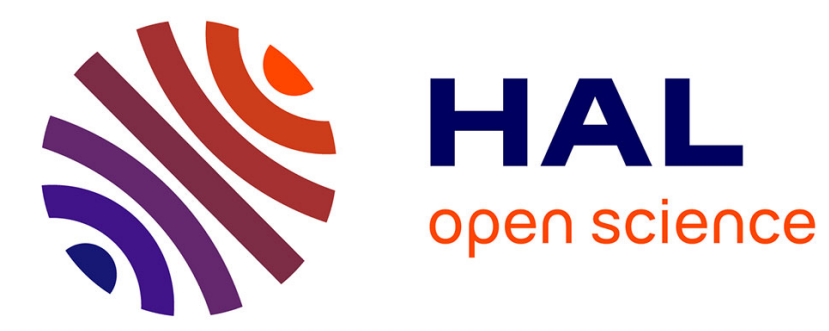

\title{
Special issue on mathematics for the fluid Earth
}

Tobias Kuna, Sandro Vaienti

\section{- To cite this version:}

Tobias Kuna, Sandro Vaienti. Special issue on mathematics for the fluid Earth. 2015, 10.1088/17518113/48/14/140201. hal-01258392

\section{HAL Id: hal-01258392 \\ https://hal.science/hal-01258392}

Submitted on 21 Jan 2016

HAL is a multi-disciplinary open access archive for the deposit and dissemination of scientific research documents, whether they are published or not. The documents may come from teaching and research institutions in France or abroad, or from public or private research centers.
L'archive ouverte pluridisciplinaire HAL, est destinée au dépôt et à la diffusion de documents scientifiques de niveau recherche, publiés ou non, émanant des établissements d'enseignement et de recherche français ou étrangers, des laboratoires publics ou privés. 


\title{
Special issue on mathematics for the fluid Earth
}

\author{
Tobias Kuna ${ }^{1}$ and Sandro Vaienti ${ }^{2,3}$ \\ Guest Editors \\ ${ }^{1}$ Department of Mathematics and Statistics, University of Reading, Whiteknights, \\ PO Box 220, Reading RG6 6AX, UK \\ ${ }^{2}$ Aix Marseille Université, CNRS, CPT, UMR 7332, 13288 Marseille, France \\ ${ }^{3}$ Université de Toulon, CNRS, CPT, UMR 7332, 83957 La Garde, France \\ E-mail: t.kuna@reading.ac.uk and vaienti@cpt.univ-mrs.fr
}

Keywords: special issue, fluids, mathematics

This is a call for contributions to a special issue of Journal of Physics A: Mathematical and Theoretical dedicated to mathematics for the fluid Earth. The fluid Earth is an excellent example of a forced, dissipative non-equilibrium system dominated by nonlinear processes featuring multi-scale interactions. The full spectrum will be considered: the issue will consist of reviews and original research articles from mathematical papers addressing general questions, articles considering these questions for more realistic problems on the level of rigour in theoretical physics and articles that apply new mathematical tools to concrete physical situations with application to the Fluid Earth system. The objective is to catch the complexity of this system and its phenomena as a statistical manifestation of large-scale systems in the asymptotic regimes far from the equilibrium where loss of memory and recurrence prevail. Through excellent scientific contributions, we aim to present the interplay between theoretical, numerical and computational techniques that is necessary to unravel the structure of Planet Earth.

\section{Editorial policy}

The guest editors of this issue are Tobias Kuna and Sandro Vaienti.

The areas and topics of issue include, but are not limited to:

- PDEs of geodynamical fluids

- dynamical systems and equilibrium and non-equilibrium statistical physics

- random systems and their statistics

- extremes and tipping points

- mathematics in atmospheric and oceanic flow, hydrology, and climate science

All contributions will be refereed and processed according to the usual procedures of the journal. 


\section{Guidelines for preparation of contributions}

- The issue will be open for submissions from 1st April to 1st August 2015 and articles will appear in regular issues of the journal and in an online collection.

- There is no strict regulation on article size, but as a guide the preferable size is 15-30 pages for contributed papers and 40-60 pages for reviews. Further advice on publishing your work in Journal of Physics A may be found at iopscience.iop.org/jphysa.

- Contributions to the special issue should be submitted by web upload via ScholarOne Manuscripts quoting 'JPhysA special issue on mathematics for the fluid Earth'. Submissions should ideally be in standard LaTeX form. Please see the website for further information on electronic submissions.

- All contributions should be accompanied by a read-me file or covering letter giving the postal and e-mail addresses for correspondence. The publishing office should be notified of any subsequent change of address. 